\title{
Preservation strategies for student affairs records at the University of Venda in South Africa: a preliminary study
}

\author{
Sidney Netshakhuma \\ University of Mpumalanga \\ Sidney.Netshakhuma@ump.ac.za
}

Received: 19 December 2019

Revised: 27 April 2020

Accepted: 21 June 2020

\begin{abstract}
Student affairs records are essential components in addressing basic functionalities in the university environment as they serve diverse purposes such as the life of a student on the campus. However, these records are often not preserved properly especially at universities in rural settings. This study assessed student affairs records, with consideration to preservation strategy at the University of Venda in South Africa. Data were collected through interviews with ten purposively selected staff members from student affairs division. The key findings reveal that while the university has an archive service within the library, the responsibility of preserving student records lies with records management division that resides within the registrar's office. However, there is no preservation strategy for student affairs records. It is concluded that collaboration between student affairs and records and archives department enhance to collect the student affairs records. A comprehensive study on the management of student affairs records in South African universities is recommended.
\end{abstract}

Keywords: archives, record management, student affairs records, preservation strategy, University of Venda

\section{Introduction and background of the study}

The role of student records in educational institutions cannot be over-emphasised. The preservation of student affairs records is essential for a university's history, as well as proof that certain people are the alumni of the institution. The concept of student affairs record, as defined by Wagner and Smith (2012), refers to a record of extracurricular activities, clubs, performances, sports teams and student life, material reflecting residential life, student publications and student social life. Such records are created across a broad spectrum of student life and activities such as sports and culture (Garaba 2018). Student affairs records are extracurricular activities performed by students that fall outside the realm of the normal curriculum of university education. Such activities are generally voluntary, social, and philanthropic such as sports and drum activities. With student affairs definition in mind, one may observe that there are various records created by student organisation bodies. Most of the time these records are neglected and not incorporated within the university's records management system.

The problem of documenting records generated in extracurricular activities is that they are transitory material and therefore have a relatively short lifespan (Garaba 2018). Furthermore, sometimes these records are generated by the students themselves and the university does not have 
access to them or even aware of their existence. The student affairs records need to be included in the university's collection because students constitute the largest group of the institution (Michele 2002; Netshakhuma 2019d). This study assessed student affairs records, with consideration to preservation strategy at the University of Venda in South Africa.

\subsection{The historical background of the University of Venda}

The University of Venda was established in 1982 as a comprehensive institution in a rural setting. The comprehensive universities provide a combination of both traditional university qualifications such as bachelor's, master's and doctoral programmes and universities of technology qualifications such as a certificate to doctoral qualifications. The university has campuses based in the Limpopo province, with the Thohoyandou Campus as the main campus.

The records and archives department was established in 1990 as part of the library to preserve institutional memory (Sulej 2009). Archives repository preserve research activities and creative efforts of students' records of the university (Miner \& Kahl 2012). The university archivist was appointed in 2015. The university archives aim to preserve archival material to enhance accessibility. The university archivist's first task was to appraise student records. The focus was aimed at processing students' files so they would be available for use by researchers. The second task was to develop a records and archives management policy to consider the kinds of archives that might be included in the corporate institutional archives. In the policy, student affairs records were regarded as the institutional memory by the university community.

\section{Problem statement}

Although university student affairs records are a fundamental element of the archives and records management programme, these records are often neglected in many institutions. Indeed, preserving student affairs records is one of the problems faced by most of the South African universities. Chinyemba and Ngulube (2005) observed then that while the majority of records managers and archivists recognise the importance of documenting student affairs records, they lack a preservation strategy. The study conducted by Segaetsho and Mnjama (2012) indicated that the preservation of archival materials in Africa has not received adequate attention. The lack of preservation strategy contributed to ineffective collaboration between records and archives and student affairs divisions to preserve records and prevent loss of records (Wagner \& Smith, 2012; Samuels 1992; Mnjama, Mooko \&Manewe-Sisa 2016; Segaetsho \& Mnjama 2012; Millar 1997; Ambira \& Kemoni 2011; Erima \& Wamukoya 2012; Netshakhuma 2019a; 2019b; 2019c; 2019d). Few studies have examined student affairs records preservation strategies (Kezar 2003). It is this background that informed this study; hence, the research sought to assess the present state of student affairs records at the University of Venda.

\section{Purpose and research questions}

The main purpose of this study was to assess student affairs records with the view to recommend a preservation strategy. The following research questions guided the study:

* RQ1: How were student affairs records preserved at the University of Venda?

* RQ2: What is the level of collaboration between student affairs and the records and archives department to preserve student affairs records at the University of Venda? 


\section{Literature review}

Literature review according to the objective of the study emanated from the research questions.

\subsection{Preservation of student affairs records}

Preservation of records ensures the protection of historical and cultural records of enduring value. In case of university archive, it entails preservation of a history of the student activities (Millar 1997). For example, the institutional archives of the Maritime University of Szczecin in Poland and the University of Ottowa in the United States of America were resourced for the student society's memory due to an inextricable link with the university's history and its scientific, didactic, cultural and social activity (Zalewska 2015; Bowker \& Villamizar 2016). In South Africa, the initiative was taken to establish archives departments to preserve archives materials. The study conducted by Sulej (2009) as indicated in Table 1 demonstrated the year of some of the South Africa university archives establishment.

\begin{tabular}{|l|l|}
\hline Name of universities & Year of archives establishment \\
\hline University of Cape Town & 1960 \\
\hline University of the Western Cape & 1978 \\
\hline University of Venda & 1990 \\
\hline $\begin{array}{l}\text { The University of Port Elizabeth ( Now known as the } \\
\text { Nelson Mandela University }\end{array}$ & 1974 \\
\hline University of Pretoria & 1994 \\
\hline UNISA & 1973 \\
\hline University of Johannesburg & 1980 \\
\hline
\end{tabular}

Table 1 Establishment of South Africa Archives (Sulej 2009)

The review of the literature shows that the above-mentioned university archives preserved only corporate archives such as council minutes and annual reports (Netshakhuma 2019a). Records about student affairs records were not included in archives repositories of universities. The study conducted by Rozum and Brassaw (2014) indicated that a comprehensive records and archives management programme requires universities to develop a strategy to preserve student affairs records. For example, the Loyal University of Chicago in the United States of America developed a preservation policy to preserve university archives. University archives and records management strategy is to be aligned to the corporate one (Kulcu 2009). Records management strategy is to be informed by the university policies, rules and procedures (Chinyemba \& Ngulube 2005). Abankwah (2011) emphasises that the level of preservation is upheld by the policies and strategies that universities put in place. Failure to adhere to established standards in the management of student records should be a cause of concern in Southern African countries. The records management framework is essential to promote the management of students records and guarantee the survival of documentary materials for enduring access, use and re-use (Mkuwira 2015). According to Mnjama (2002:310), there is evidence of negligence of records management in universities because of the absence of a coordinated and planned records and archives management programme.

Management of student affairs records is an integral part of comprehensive archives and records management programme (Popoola 2007). The study conducted by Miner and Kahl (2012) 
indicated that most of the African universities lack an integral strategy to manage student affairs records throughout the records' lifecycle. The interconnectedness of divisions is an integral part of managing university records that raises issues of archiving student affairs records. This means that the preservation of student records achieved through a collaboration between faculty officers, archivists and students. The transformation in universities is visible in increased collaboration and integration. Institutional incorporation requires stakeholder involvement (Milos 2017).

A review of the literature demonstrated that student affairs records are not managed in terms of legislation such as the National Archives and Records Service of South Africa Act (Act. 43 of 1996, as amended) as often universities are exempted from archival legislation (Chachage \& Ngulube 2006; Netshakhuma 2019a; Chinyemba \& Ngulube 2005). Hence, the South African university records and archives management departments need to be guided by the requirements of the Promotion of Access to Information Act (No. 2 of 2000) (PAIA) and the Protection of Personal Information Act (No. 4 of 2013) (Netshakhuma 2019c).

There is a gap in South African universities regarding preserving student affairs because of a lack of proper archives buildings to store records with archival value and lack of appraisal of records processes to determine records with archival value. The process of conducting an appraisal of records to determine records with archival value starts with the development of a file plan. This statement is alluded to by Ngoepe and Nkwe (2018) who indicate that most of South Africa departments lack appraisal of records. The file plan categorises all records created by universities (Vellino \& Alberts 2016). A file plan is fundamental to aspects of records management (Cheng 2018). University archives play a role in the development of student records. Student affairs records are to be appraised and preserved for research.

According to Yusuf and Chell (2005), preserving records poses a challenge to long-term access and the review of the literature showed a lack of long-term preservation of student records (Primer 2009). Hence, there is a need for student affairs officials to preserve student affairs records. Such archival materials are to be described and analysed in detail to understand the lifestyle of students in universities. The history of student organisations and their stories concerning the university find their reason for being in the opportunity they offer to reflect strategically on how university orient towards itself and the external stakeholders (Cartwright \& Magni 2015).

The initiatives to preserve student affairs are taken to enhance research activities (Kuh, Cruce, Shoup, Kinzie \& Gonyea 2008). Student affairs records served as a research collection for future generations to understand the history of student affairs. Archivists must play a role in assisting students to examine student records. Records help to support the decision-making of lecturers through elicited knowledge that promotes efficiency and effectiveness of teaching and learning (Cheng 2018). According to Rhee (2015), one aspect of information seeking is access to archival materials, especially access tools.

\subsection{Collaboration between student affairs and records and archives department}

The literature on university records management stresses the importance of collaboration between archivists and other stakeholders such as student affairs officers and compliance officers (Bowker \& Villamizar 2017: 61; Donaldson \& Bell 2018). The collaboration of university archivists, student affairs divisions and compliance officers enhance collection and preservation of student affairs records as alluded to by Masanes (2006) and Kezar (2003). 
The study conducted by Egwunyenga (2009) stated that most of the universities based in Nigeria lack a strategy to build internal stakeholders to enhance the preservation of student affairs records. Rozum and Brassaw (2014) alluded that there is a lack of partnership between the students' affairs division and the records and archives division to enhance the preservation of student affairs records. Universities are hesitant to undertake a partnership initiative to build internal stakeholders aware of the importance of student affairs of records ((Bull \& Eden 2014). To preserve student affairs records, a strategy needs to be developed to enhance collaboration between executive management, faculty boards, archivists and students (Rozum \& Brassaw 2014). It appears that most universities from developing countries lack a strategy to support a partnership and collaboration of students (Young 2012).

Partnerships and collaborations can be initiated between universities and communities surrounding universities to enhance the preservation of student affairs records. Students interact with communities surrounding universities on community projects and sponsorships. According to Chung (2018) and Netshakhuma (2019c; 2019d; 2020), institutions should be accountable to society by creating and retaining knowledge via records and archives.

\section{Research methodology}

This study collected data through interviews with ten (10) purposively selected sample from staff members responsible for management of student affairs records. Purposive sampling was used to gain insight into the importance of student affairs records as participants were more familiar with student affairs records within the university. An interview guide was developed to guide the interactions with the identified respondents. The interviews were conducted within four weeks in 2018. All the interviews were recorded. As this was a preliminary study, the questions were focused on two issues, that is, availability of strategy for student affairs records, as well as collaboration between student affairs and archives department in managing such records.

\section{Findings and discussion}

This section analyses and presents the results of the data obtained via interviews.

\subsection{Preservation of student affair records}

To answer this question respondent was asked about the availability of a strategy to manage student affairs records. Based on the responses, it is clear that the majority of participants (9: 90\%) were not aware of the strategy to manage student affairs records. Only one (10\%) participant indicated that the records and archives department had developed a strategy to manage all types of records. This participant indicated that although provision is also made for student affairs records in the generic strategy, these records often falls outside the jurisdiction of the university. "In other words, the University has no control of the records whatsoever. I think it should beclear in the policy to encourage students to donate their records to the University. However, the University should do appraisal of such records as some students might not have impact". This participant provided example of records of Onkgopotse Tiro (student activist at the University of The North in the late 1970s), that such could have value to the University of Limpopo where he studied. 
It is clear that the participants were not aware of the importance of records and archives management programmes in universities. The fact that there was no student affairs strategy implies that records are not managed according to records and archives management principles. This finding is alluded to by Garaba (2018) who indicates in his study that the neglect of the student affairs records could be due to the lack of awareness and a recordkeeping culture within universities.

\subsection{Collaboration between student affairs and the records and archives department}

All the participants stated that there was a lack of collaboration and partnership between records and archives management officers and student affairs officials. Furthermore, one participants indicated that "while the university has an archive service within the library, the responsibility of preserving student records lies with records management division that resides within the registrar's office. However, there is no preservation strategy for student affairs records. Collaboration between student affairs and records and archives department enhance to collect the student affairs records".

The lack of collaboration between records and archives departments and university archives limits the collection of extra-activities student affairs records. The student affairs officials acknowledged that collaboration with the university archives was limited. This statement is corroborated by Garaba (2018) who indicates that the success of a records and archives management programme depends on the existence of a partnership and collaboration framework to enhance the management of records. Carter (2006) indicates that university archivists should work to fill documentary gaps, missing traces or archival silences. It seems there were limited resources to manage records.

\section{Conclusion and recommendations}

The empirical study reveals gaps in the preservation of student affairs records. The study found that the university lacks a strategy to preserve student affairs records and the absence of collaboration and partnership between records and archives management division and students affairs department. The development of comprehensive records and archives management strategies that incorporate internal departments would enhance the management of student affairs records. It is recommended that:

- The records and archives division should develop strategies to preserve student activities records. This means that universities establish, directed and coordinated set activities associated with maintaining student affairs records. Strategies include the conditions of the storage media, ensuring that proper student affairs records are kept.

- There is a need for the university to interconnect with students, student organisations and communities surrounding universities to enrich the student experience through research and engagement. For the records and archives division to collect student affairs records requires the collaboration of divisions, units and sections to collect student affairs records with historical and cultural values.

As Ngoepe and Ngulube (2011) would attest, the overview provided in this study has obvious limitations due to small sample form one university. Therefore, a broader study with a larger 
sample on the management of student affairs records in South African universities is recommended.

\section{References}

Abankwah, MR. 2011. Policies and strategies that govern the management of audio-visual materials in Eastern and Southern Africa Regional Branch of the International Council on Archives. Journal of the South African Society of Archivists 44: 99-106.

Ambira, C. \& Kemoni, H. 2011. Records management and risk management at Kenya Commercial Bank Limited. Journal of Information Management 13(1): 475-480.

Bowker, L. \& Villamizar, C. 2017. Embedding a records manager as a strategy for helping to positively influence an organisation's records management culture. Records Management Journal 27(1): 57-68.

Bull, J. \& Eden, B.L. 2014. Successful scholarly communication at a small university; integration of education, services, and an institutional repository at Valparaiso University. College \& Undergraduate Libraries. Libraries Journal 21: 263-278.

Carter, R.G.S. 2006. Of things said and unsaid: power, archival silences, and power in silence. Archivaria 61: 215-33.

Cartwright, S. \& Magni, L. 2015. The value of stories in understanding the past and shaping the future in merged organisations. In Advance in Mergers and Acquisitions. Published online. https:// dx.do: org/10.1108/51479-361.

Chachage, B. \& Ngulube P. 2006. Management of business records in Tanzania: an exploratory case study of selected companies. South African Journal of Information Management 8(3).

Cheng, C.K.E. 2018. Managing records and archives in a Hong Kong School: a case study, Records Management Journal 28(2): 204 -216.

Chinyemba, A. \& Ngulube, P. 2005. Managing records at higher education institutions: a case study of the University of KwaZulu-Natal, Pietermaritzburg Campus. South African Journal of Information Management 7(1).

Donaldson, D.R. \& Bell, L. 2018. Security, archivists and digital collections. Journal of Archival Organisation 15(1-2): 1-19.

Egwunyenga, E.J. 2009. Record keeping in universities: associated problems and management options in South West Geo-Political Zone of Nigeria International Journal of Educational Sciences 1(2): 109-113.

Erima, J.A. \& Wamukoya, J. 2012. Aligning records management and risk management with business processes: a case study of Moi University in Kenya. Journal of the South African Society of Archivists 45: 24-38.

Garaba, F. 2018. The neglected fond in university archives. The case of sport club records at the University of Kwazulu-Natal (UKZN), Pietermaritzburg Campus, South Africa. Records Management Journal 28(2): 143-158.

International Records Management Trust (IRMT). 1999. Managing public sector records: a study programme. managing archives. London: Department for International Development.

Kalusopa. T. 2011. Developing an e-records readiness framework for labour organisation in Botswana. Unpublished PhD Thesis, University of South Africa, South Africa.

Kezar, A. 2003. Enhancing innovative partnerships: Creating a change model for academic and student affairs collaboration. Innovative Higher Education 28(2): 137-156.

Kuh, D.G., Cruce, M.T., Shoup, R., Kinzie, J. \& Gonyea, M.R. 2008. Unmasking the effects of student engagement on first-year college grades and persistence. Journal of Higher Education 79(2): 540-563. 
Kulcu, O. 2009. Records management practices in universities: A comparative study of examples in Canada and Turkey. The Canadian Journal of Information and Library Science 33(1/2): 86-107.

Masanes, J. 2006. Web archiving. Heidelberg: Springer.

Michele, C. 2002. Documenting student life. The use of oral histories in university archives. IOWA State University. DOI: lib.dr.iastate.edu/cgi/view ontent.cgi.

Millar, L. 1997. Principles of records and archives management. London: ICA/IRMT.

Milos, V. 2017. SPAcS: Post-merger Survival. Managerial Finance 43(1).

Miner, M \& Kahl S.D. 2012. Collecting campus culture: Collaborations and collisions. Journal of Librarianship and Scholarly Communication 1(2): 2-7.

Mkuwira, R.M. 2015 Preservation of documentary heritage in Malawi. Journal of the South African Society of Archivists 48: 55-65.

Mnjama, N., Mooko, P.N. \& Manewe-Sisa, P. 2016. Customer service at the records management unit of Botswana Ministry of Labour and Home Affairs. Africa Journal of Library, Archives and Information Science 26(2): 155-166.

Mnjama, N.M. 2002. Managing university records. ESARBICA Journal 21: 32-40.

Netshakhuma, N.S. 2019a. The role of archives and records management legislation after colonialism in Africa: Case of Southern Africa. Records Management Journal 29(1/2): 210223.

Netshakhuma, N.S. 2019c. Assessment of the management of student affairs records: Case of the University of Mpumalanga in South Africa. Records Management Journal ahead-of print DOI: https://doi.org/10.1108/RMJ-01-2019-0004.

Netshakhuma, S. 2019b. The blurry line between archives and records management at the universities in South Africa. Journal of the South African Society of Archivists 52: 61-78.

Netshakhuma, S. 2020. An analysis of the adoption of e-voting system at the University of Mpumalanga. Conference Proceedings of University of Zululand $20^{\text {th }}$ Annual information Science conference.

Netshakhuma, N. 2019d. Analysis of South African universities and communities archives. Global Knowledge, Memory and Communication 68(8/9): 635-651.

Ngoepe, M. \& Ngulube, P. 2011. Assessing the extent to which the National Archives and Records Service of South Africa has fulfilled its mandate of taking the archives to the people. Innovation 42(1): 3-22.

Ngoepe, M. \& Nkwe, M. 2018, Separating the wheat from the chaff with the winnowing fork: The eeny meeny miny mo appraisal approach of digital records in South Africa. Records Management Journal 28(2): 130-142.

Pereira, R. 2017. Assessing the implementation of the National Archives and Records Services Act at Eduardo Mondlane University in Mozambique. ESARBICA Journal. 37: 221-239.

Popoola, S.O. 2007. Workplace, biographical and motivation factors affecting organisational commitment of records officer in Nigerian federal universities. African Journal Library, Archives and Information Science, 17 (1): 33-44.

Primer, B. 2009. Resources for archives: developing collections, constituents, colleagues, and capital. Journal of Archival Organisation 7: 58-65.

Rhee, H.L. 2015. Reflections on archival user studies. Reference and User Service Quarterly, 54(4): 29-42.

Rozum, B. \& Brassaw, L.J. 2014. Merging two academic libraries: Finding unity from diversity while maintaining institutional identities. In Mergers and alliances: The operational view and cases. Published online: 20 August 2014. 
Samuels, H.W. 1992. Varsity letters: Documenting modern colleges and university Chicago: Scarecrow Press.

Segaetsho, T. \& Mnjama, N. 2012. Preservation of library materials at the University of Botswana Library. Journal of the South African Society of Archivists 45: 68-73.

Sulej, Z. 2009. Changing landscapes; the university archives in a new South Africa. ESARBICA: Journal of the Eastern and Southern Africa Regional Branch of the International Council on Archives 28(1): 19-29.

Vellino, A. \& Alberts, I. 2016. Assisting the appraisal of e-mail records with automatic classification. Records Management Journal 26(3): 293-313.

Wagner, L.J. \& Smith, D.A. 2012. Students as donors to university archives: A study of student perceptions with recommendations, The American Archivists 75(2): 535-566.

Young, K. 2012. Planning a congressional archive at Loyola University Chicago. Journal of Library Administration 52: 341-350.

Yusuf, M.Z. \& Chell, W.R. 2005. Issues in records management. Bangi: Penerbit Universiti.

Zalewska, M. 2015. The institutional archive of the Maritime University of Szczecin. Scientific Journal of the Maritime University of Szczecin, 140-144. 